\title{
Mark 4:1-34: A simple structure for the mystery of the kingdom
}

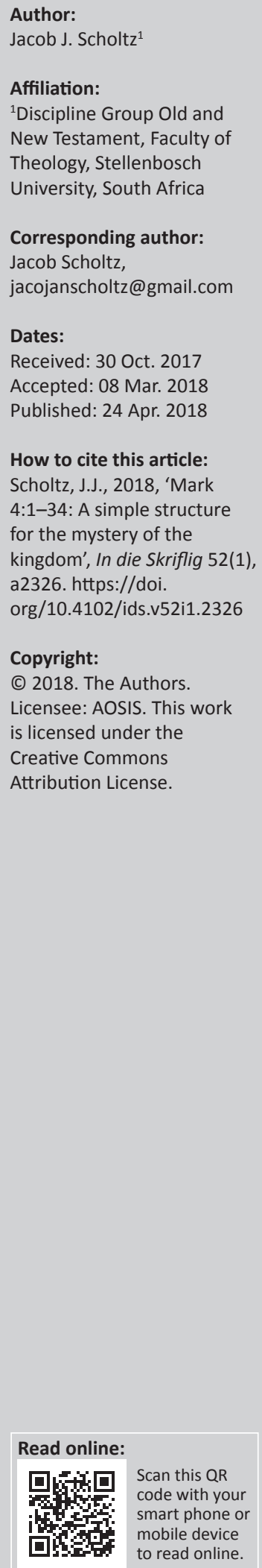

Existing proposals regarding the structure of Mark 4:1-34 have not met with unqualified approval. This article proposes a simple structure for Mark 4:1-34, then highlights relevant presuppositions before providing an overview of the content of this passage. The structure elevates the parable of the lamp to a prominent position and it also pairs corresponding sections so that it becomes easier to identify the mystery that undergirds each of these parables. The collective message of Mark 4:1-34 may be that while the establishment of the Messianic kingdom has been postponed, God is sowing the word, not only in Israel, but all over the world. When the sowing of the word meets with a responsive ear and heart, God gives the believer the mystery of the kingdom and, viewed collectively, God will also bring a harvest of sons and daughters into the kingdom when it is established. It is important for all to hear, not only so that the hearers become believers and then to bear some fruit, but also because God will graciously bless to the extent that a person listens effectively. It is in this context that the parable of the lamp shines new light on Mark's parabolic discourse.

\section{Introduction}

Few acknowledge what Cranfield (1966:164) rightly emphasises regarding the parable of the lamp (Mk 4:21-23), namely that Mark does not regard verses 21 and 22 as 'proverbial wisdom or moral exhortation, but as containing the mystery of the kingdom of God'. When discussing the mysteries of the New Testament, the parable of the lamp receives no mention from Wiley (1985:349-360), Fruchtenbaum (2004:651-696) or from Beale and Gladd (2014:56-83). Instead, the Matthean mysteries of the kingdom of heaven (Mt 13:1-52) receive all the attention, neatly outlined and structured, only to be appended by a unique Markan parable (4:26-29) that sticks out like a sore thumb. However, Mark 4:1-34 is not only structured, it also contains an integrated set of parables that collectively describes the mystery of the kingdom of God. After discussing two existing proposals, the first purpose of this article is to submit a simple structure for verses 1-34. Presuppositions that influence an understanding of verses 1-34 are then disclosed. The article concludes with its second purpose, namely to provide an overview of the teaching of this passage.

\section{A chiastic structure proposed for Mark 4:1-34}

Mark clearly structured verses 1-34 to be read as a unit (Dewey 1980:150; Lambrecht 1977:118120). Editorial bookends undoubtedly frame the material (vv. 1-2, 33-34), as references to 'many parables' (vv. 2, 33), 'teaching' (vv. 1, 33) and 'the crowds' (vv. 1, 34) are mirrored at the start and conclusion of this body of teaching. This framing also contains a contrast: Jesus spoke many parables to the crowds to whom he spoke only in parables, but when he was by himself with his disciples, he explained all things to them (vv. 1-2, 33-34). Viewed broadly, verses 1-34 can be viewed as a 'Markan sandwich' (Edwards 2002:126; Lambrecht 1977:116) - A (vv. 1-2), B (vv. 3-32), A' (vv. 33-34) - but more structuring is evident.

There are two popular chiastic proposals for verses 1-34. The first, by Dewey (1980:150; see also Lambrecht 1977:115), is a five-part structure. See Figure 1.

For Dewey (1980:152), the 'symmetrical rhythm employed in 4:1-34 functions to highlight the contrast or paradox of parables as a means of revelation and as riddles'. Section B contains two major parable units (the parable of the sower and its interpretation), which are paired with two parables in section B' (Dewey 1980:150). Whereas Dewey (1980:149; see also Lambrecht 1977:115) considers section $B$ to be itself arranged in a five-fold chiastic structure (a 2b-9; b 10; c 11-12; $b^{\prime} 13$; $a^{\prime} 14-20$ ),

1.Further references to Mark 4 will be indicated only by verses. 


A Introduction vv. 1-2a
B Parable material vv. 2 b-20
C Sayings material vv. $21-25$
B' Parable material vv. $26-32$
A' Conclusion vv. 33-34

FIGURE 1: A five-part chiastic structure by Dewey (1980:150).

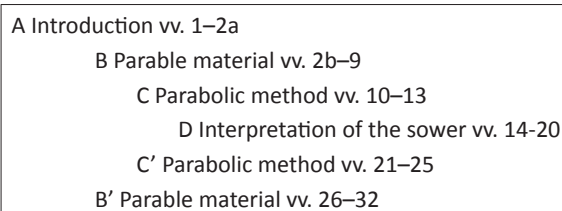

FIGURE 2: A seven-part chiastic structure by Fay (1989:69).

section $\mathrm{B}^{\prime}$ is not symmetrically arranged. At the centre of the proposed structure, section $\mathrm{C}$ is considered to have 'general sayings material, not parables strictly speaking' (Dewey 1980:151). Section C, 'with its idea of everything being made manifest and coming to light, counters the idea that the purpose of parables is to hinder understanding' (Dewey 1980:151).

Fay (1989:67) reacts to the above proposal by arguing that the antithetical middle term of section B, that is verses $11-12$, cannot become the more general theme of the discourse. According to Fay (1989:67), it seems inconsistent to posit understanding as the 'broader theme of vv. $2 b-20$, interposed by the notion of obscurity in vv. 11-12, and then to conclude the primary theme of vv. 1-34 to be that "parables are incomprehensible riddles to outsiders"'. Fay (1989:69) therefore made a second proposal - a seven-part chiastic structure, see Figure 2.

Fay (1989:66) holds that the proposed structure 'functions to introduce one of the predominant themes of the gospel: the incomprehension of the disciples'. He (Fay 1989:70) states: '[The] parallelism of vv. 10-13 and 21-25 within this chapter is the distinctive feature of the new pattern I proposed'. Proposed parallelisms between section C (vv. 10-13) and C' (vv. 21-25) include: first, the fact that 'parable theory expressed in vv. 10-13 cannot be accurately understood unless it is balanced by the equally important statement of vv. 21-25' (Fay 1989:68); second, thematic and vocabulary parallels between 'mystery' (v. 11) and 'hidden' (v. 22), between hearing (in vv. 12 and 24), and viewing verses 11 and 25 as forming inclusios with each other (p. 68); and (3) proposing that both section $C$ and $C^{\prime}$ are structured as small chiasms (p. 70-73).

The major concern regarding both proposals is that verses 21-25 contain parables - not mere 'sayings' (c. Dewey 1980:151) and it is not about 'parabolic method' either (c. Fay 1989:69). The start and conclusion of this parabolic discourse (vv. 2, 33) note that Jesus spoke to them in parables, not in sayings. Moreover, verse 34 adds that Jesus did not speak to them without a parable. ${ }^{2}$ In agreement with Blomberg

2.The definition and description of a parable by Sider (1995:259; cf. also Blomberg 2012:51-55) is endorsed, that is, a parable is a 'saying that is labelled parable in one $2012.51-55$ ) is endorsed, that is, a parable is a saying that is labelled parable in on of the Gospels, or any similar saying of Jesus. It expresses or implies the logic of analogy in the language of either simile or metaphor elaborated into a form of allegory that is selectively, but not pervasively, symbolic. Often this allegorical elaboration of the image of a parable is narrative - usually creating a story-parable, but occasionally an example-story.

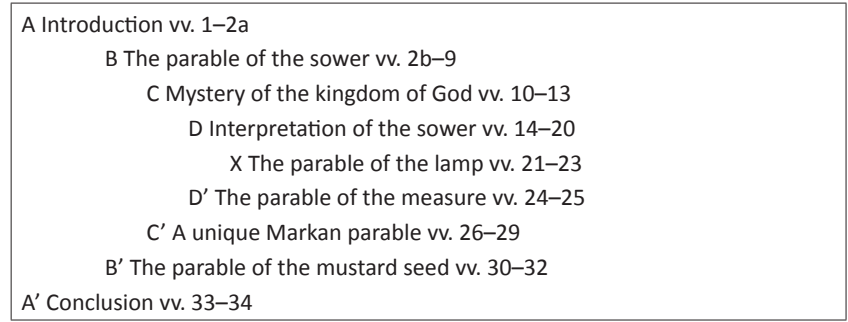

FIGURE 3: A nine-part chiastic structure, as proposed.

(2012:133), the outline, proposed by Fay, 'requires Mk 4:21-25 to represent "parabolic method" rather than "parabolic material", which seems unlikely'. Further, reacting against Dewey's proposal, Fay (1989:68) notes that section B (vv. 2b-20) is much lengthier and thus 'overbalances' the corresponding section B' (vv. 26-32). One may also add that section B' of both proposals link two parables (vv. 26-32) with a corresponding section $\mathrm{B}$ that contains only one parable; perhaps another 'unbalanced' position. Because both these chiastic structures may be doubted one way or another, I would urge us to consider yet another. Perhaps a simple structure is hiding in plain sight.

Outside of the bookends (vv. 1-2, 33-34), narrative descriptions by the evangelist are few. It also occurs in verse

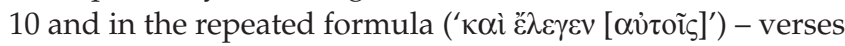
9, 11, 13, 21, 24, 26, 30) when Mark reports 'and He said [to them]'. A change of scene is implied in verse 10, as Jesus privately answers a question posed by his followers (4:10-20; see v. 34). When Mark notes in verses 21 and 24 that Jesus spoke 'to them', some take this as a continuation of the private discussion, because this is not only in harmony with Mark's most recent usage (vv. 11, 13), but also because verses 21-25 are 'especially suitable to the circle mentioned in verse 10' (Hiebert 1994:115-117; see also Fay 1989:69). However, based on the resumption of parabolic speech (Edwards 2002:139) as well as the repeated call to listen (v. 23; see also v. 9), France (2002:186) suggests that verses 21-25 were probably spoken in public to the crowds. While the crowds heard many parables $(4: 1-2,33-34)$, the text does not say they heard all of them. Further, the call to listen in verse 23 does not necessarily mean the crowd heard it too like they did in verse 9. It therefore seems more likely that verses $21-25$ was spoken to Jesus' followers, and not to the crowds. If this is true, and considering only verses $1-34$, then the outsiders heard only three parables (vv. 3-9, 26-29, 30-32). ${ }^{3}$ But regardless of whether one holds that verses 21-25 was spoken to Jesus' disciples only or also to the crowd, if the evangelist's few narrative descriptions are used as section dividers,

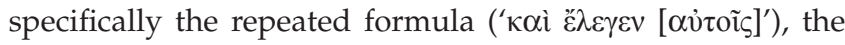
following chiastic structure in Figure 3 may present itself.

Sections A and $\mathrm{A}^{\prime}$ are indisputably bookends or corresponding pairs of the outline of verses $1-34$, but a proposed chiastic structure becomes more plausible if major themes are repeated not only in the first and last sections (A and $\mathrm{A}^{\prime}$ ), but also in the centre (Blomberg 1989:7). In this 3.In Matthew's presentation of the same day's events, it is clear that the outsiders missed out on at least four parables (Mt 13:36-52). 
case, teaching indirectly by way of parables (A 4:1-2; $\mathrm{A}^{\prime}$ $4: 33-34)$ is matched with a parable that promises that what is hidden will eventually be revealed, and what is secret will be brought to light (X, vv. 21-22). In section $A^{\prime}$, Christ spoke the word as the crowd was able to hear (v. 33), whereas section X climaxes with a call to hear (v. 23). Moreover, the parable of the lamp includes references to light and revelation, and to hidden secrets ( $X, \mathrm{vv} .21-22)$ - but to his disciples Jesus explains everything ( $\left.\mathrm{A}^{\prime}, \mathrm{v} .34\right)$.

There can be little objection to matching the parable of the sower (B, vv. 2b-9) with the parable of the mustard seed ( $B^{\prime}$, vv. 30-32). In both cases, a sower sows seed (B, vv. 3-4; B' v. 31-32). In both cases 'birds of the air' are involved (B, v. 4; B', v. 32) - words that are not repeated elsewhere in 4:1-34. Both parables depict seed that sprang up $(B, v .8)$ or a seed that grew up $\left(\mathrm{B}^{\prime}, \mathrm{v}\right.$. 32). In both cases there is evidence for a large crop (B, v. 8) or significant growth (B', v. 32). As for conceptual parallelism, as discussed later, the parable of the mustard seed $\left(B^{\prime}\right)$ may depict a specific example of a seed multiplying manifold (B, v. 8).

Interestingly, section C (vv. 10-13) tells of the mystery of the kingdom of God which is paired with a parable unique to Mark ( $C^{\prime}$, vv. 26-29). It is God who gives the mystery of the kingdom to Jesus' followers (C, v. 11) and, in the corresponding section, it is again by God's power and superintendence that 'automatically the earth produces fruit' $\left(C^{\prime}\right.$, v. 28). Sections $C$ and $C^{\prime}$ both refer to the 'kingdom of God' (but not uniquely so in this discourse - see also v. 30). The seed of the parable ( $C^{\prime}$, vv. 26-29) takes root in the heart of believers (C, vv. 1013). While the mystery of the kingdom remains veiled to unbelievers who must repent and be forgiven for their sins (C, v. 12), believers who have been given the mystery of the kingdom of God are certainly part of the harvest ( $\left.C^{\prime}, \mathrm{v} .29\right)$.

While there are (non-exclusive) examples of verbal parallelism - such as fourfold (D, vv. 15, 16, 18, 20) and twofold references to 'hear' ( $\mathrm{D}^{\prime}$, vv. 24-25) - the thematic and conceptual parallels between section D (vv. 14-20) and D' (vv. 24-25) are striking. Regarding verse 25, Cranfield (1966:167) specifically compares the first half of verse 25 with verse 20, and the latter half of verse 25 with verses $15-19$. This fits perfectly with Jesus' teaching: disciples who heed the warning to hear, will be rewarded by receiving more - some yielding 30 -fold, some 60 - and some a 100 -fold. Those who do not have, will lose even what little they have (D', v. 25; cf. D, v. 20; see also Wenham 1989:50). Even Lambrecht (1977:125), who also proposes the first structure discussed in this article, notes that verses 24-25 develop the warnings highlighted in verses 14-20.

Dominant themes throughout verses 1-34 include effective hearing of the word, insiders and outsiders, the presentation of the mystery, parables and more. The climax or centre of the proposed chiastic structure $(X, \mathrm{vv} .21-23)$ touches on all these themes. For example, there is the explicit call to hear (v. 23) a call which reverberates throughout most of this parabolic discourse. Hidden things and secrets, now indirectly revealed, will eventually be brought to light and thereby explicitly connecting the parable of the lamp not only with parables as an indirect form of teaching, but also reinforcing the themes of mystery and revelation. As will be discussed later, the parable of the lamp is a passage worthy of its climactic position, because it emphasises the light that Jesus is and brings to be revealed fully on his glorious appearance (see Cranfield 1966:164-165; Lane 1974:165-166). Whatever else one may say about it, most mysteries in some form or another are linked to and bound up in him in whom is hidden all the treasures of wisdom and knowledge (see Beale \& Gladd 2014:321; Col 2:3). ${ }^{4}$ If so, then even the insiders, who have been given the mystery of the kingdom, still need Jesus to explain it to them (v. 34).

What strengths and weaknesses can be identified in the proposed chiastic structure for verses 1-34? The author believes the proposed structure: first, is more balanced in terms of the length of the proposed sections; second, contains clear examples of verbal and conceptual parallelism between corresponding sections; ${ }^{5}$ third, takes into account that verses 21-25 contain parables and not mere sayings or 'parabolic method'; and fourth, may elevate the parable of the lamp to a more prominent position than had previously been recognised so that this center is worthy of its position in light of its theological significance. One possible weakness is that even though verse 23 'may have rounded off the preceding teaching' (France 2002:210) of verses 21-23, some may object to seeing the parables of the lamp and the measure placed in two separate sections of this proposed chiastic structure.

\section{Mysteries and the kingdom}

Because everyone brings presuppositions to a text, it is best not to keep it hidden (it will come to light in any event), but rather to disclose as much as possible up front. Before providing an overview of the teaching of verses 1-34, presuppositions that influence an understanding of this passage are highlighted, specifically those relating to mysteries and the kingdom of God.

\section{Mysteries: Epistemological and prophetic considerations}

The parables of Mark 4 are explicitly said to contain mysteries regarding the kingdom - the same is not said of other parables of Jesus. How may this mystery-component influence an understanding of the parables of Mark 4 ?

The first influence may be epistemological. When Jesus presents the mysteries of the kingdom by uttering things kept hidden since the foundation of the world (Mt 13:11, 35; see also Mk 4:11; Lk 8:10), does this mean that these mysteries were never revealed in the Old Testament - neither directly nor even indirectly? Three basic views exist regarding

4.Some mysteries (2 Th 2:7; Rv 17:5, 7) show that God's will to unite everything under Christ (Eph 1:9-10) is actively being opposed by Satan and his kingdom (see Mt 13:19, 39; Mk 4:15, 19).

5.See Blomberg (1989:5-8) for criteria to measure the strength and weaknesses of proposed chiasms. 
mysteries and related epistemological considerations. The first view holds that for something to qualify as a New Testament mystery it 'must be something totally unrevealed anywhere in the Old Testament' so that if it 'is knowable from the Old Testament, it is not a mystery' (Fruchtenbaum 2004:651). A second view affirms that mystery constitutes revelation that had previously been hidden but has now been revealed. It refines this by arguing that the revelation of mystery is 'not a totally new revelation but the full disclosure of something that was to a significant extent hidden' (Beale \& Gladd 2014:30, [italics in the original]). A third view states that mystery in the New Testament may have been 'obliquely alluded to in the OT, but there were no clear statements or prophecies regarding it', and that it could not be 'known naturally and was kept secret since the foundation of the world until finally revealed by God in NT times' (Wiley 1985:351-352).

According to any of the afore-mentioned three epistemological views regarding mystery, whatever has been directly revealed in the Old Testament cannot be a New Testament mystery. So, the mysteries contained in the parables of Mark 4 cannot only refer to generalities such as 'growth' or 'faith', for this is clearly known from the Old Testament. To illustrate, the Old Testament directly (and indirectly) says that the Messianic kingdom will crush all other earthly kingdoms and that the Messiah's dominion will be over all the earth and all the nations (Is 2:2; Ezk 17:22-24; Dn 2:35, 44; 7:14). If one keeps this in mind when considering, for example, what the mystery in the parable of the mustard seed is, then whatever else this parable may mean, it cannot only refer to the 'growth' of the kingdom, for this is clear from Old Testament revelation. If the parable of 'the lamp that comes' is said to refer to Jesus (Edwards 2002:139; Lane 1974:164-167), then the interpretation must still show what the mystery is, for Scripture points to Christ coming (cf. Mk 1:7; Lk 24:27). This article attempts to identify the mystery that undergirds the parables in Mark 4.

A second way this mystery-component may influence an understanding of the parables of Mark 4, is that these parables may contain unconditional prophecies that will be fulfilled directly (Scholtz 2015:2-3). If so, then one can expect some specific referents contained in these parables. Snodgrass (2008:22) rightly remarks that the 'more a parable is a prophetic instrument the more we should expect the reality to show through'. The author presupposes that, regarding these parables, Jesus shows that some of the characters or objects in these parables do 'stand for' or correspond to something or someone other than themselves (vv. 3-8, 14-20; cf. also Mt 13:24-30, 36-43). In agreement with Snodgrass (2008:33; cf. also Blomberg 2012:55-58), one should not 'reject a feature of Jesus' parables because it has allegorical significance. If Jesus' figures did not bear some relation to reality, he would have no reason to use them'.

\section{The kingdom of God}

The divine intention to have a theocratic administrator ruling as a viceroy over the earth was lost in Eden, but
God immediately promised not only a Saviour, but also a messianic ruler (Gn 1:26-28; 3:15; Vlach 2017:59-70). God restored the office of a theocratic administrator, at least in a limited sense, at Sinai. This theocratic kingdom covers much of Israel's history - from Moses until the Babylonian captivity ended this theocracy (Woods 2016:24, 53; cf. Vlach 2017:93107). God warned Israel that if she neglected the Sabbath rest for the land every 7 th year, she would be removed from her land (Lv 25:1-7; Woods 2016:54). While Israel's theocratic kingdom ended with the Babylonian captivity, Beacham (1996:236) correctly points out that 'God was not finished with this kingdom. The Old Testament prophets who had forecasted its demise also consistently foretold its consummate restoration' (Lv 26:40-46; Ezk 11:14-20; Hs 1:10-11). After all, the Davidic covenant promises are eternal (2 Sm 23:5; Ps 89:1-52; Is 55:3) and culminate in an eternal seed-descendant the Son of David who is Lord (2 Chr 17:10-14; Mk 12:35-37). But while David's house, kingdom and throne will be established forever in terms of this unconditional Davidic covenant, enjoyment of the blessings of this covenant is conditional on Israel's obedience to God. Israel returned to her land 70 years after the Babylonian captivity (2 Chr 36:2023; Jr 25:11; 29:10; cf. Dn 9:2). In the meantime, God had given Daniel secrets (raz) concerning those times of the Gentiles when Israel would have no king on David's throne (cf. Scholtz 2014:2). According to mysteries presented in Daniel 2, the four Gentile empires will eventually be crushed, and God will establish a kingdom which will never be destroyed (v. 44). The Messiah will mediate the rule of God in history on earth before this earthly kingdom will merge with God's eternal kingdom (Dn 2:44; cf. also 7:14, 18, 27).

Even though the Son of David received the right to rule the kingdom in Israel (Mt 3:16-17; Lk 1:32-33), his exercise of this rule is contingent upon Israel accepting him as the messianic king (Dt 17:14-15; Scholtz 2014:3; Woods 2016:55). Jesus offered to establish the Messianic kingdom for Israel in accordance with many unconditional Old Testament prophecies - and to do so by way of the cross (Mk 1:14-15; 10:45; Mt 4:17; 10:5-7; 15:24). The Old Testament reveals what would have happened if Israel had accepted Jesus. After noting that the eschatological programme of the Old Testament did not have the Church age in view, Toussaint (1980; cf. Constable 2017:15) states:

The program of the Lord in case of His acceptance by Israel would be in this order: (1) the acceptance of Jesus as the Messiah, (2), the cross, (3), the seven years of Jacob's trouble, and (4) the return of the Messiah to establish the kingdom. (p. 64)

Regarding step 2, the timing of Christ's cross was not contingent. Constable (2017:57-58) rightly emphasises that, if the Jews accepted their Messiah, Christ would still have died on the cross and experienced resurrection and ascension in fulfilment of many Old Testament prophecies (Ps 22; Is 53; Dn 9:24-27; Zch 13:7a; cf. Mk 10:45).

To convince that generation of Jews that he indeed is the Son of David (cf. Mk 12:35-37), Christ authenticated his Messianic claims through his words and deeds. Moreover, 
Jesus performed 'Messianic miracles': the healing of a Jewish leper (Mk 1:40-45), healing a person born blind (Jn 9:1-41) and exorcising a demon that caused muteness (Mt 12:22). After exorcising a demon from a blind and mute person (Mk 3:20-30; cf. Mt 12:22-32), the religious leaders, who represented Israel, not only rejected the Messiahship of Jesus, but did so on the basis that Jesus had 'an unclean spirit' (Mk 3:30). This blasphemy of the Holy Spirit cannot be forgiven (Mk 3:29). The unforgiveable sin in this context is:

hardened and willful rejection of the Messiah who was standing before them and doing miracles in the power of the Holy Spirit. It was an inexcusable rejection of the Messiah and his kingdom. (Vlach 2017:323)

The result was that Jesus rescinded the offer of the Messianic kingdom for Israel at that time and for that generation of Jews who lost out on the privilege of seeing the kingdom established in their day. This kingdom 'is now destined to be re-offered to the Jewish generation of the Tribulation, and that generation will accept it' (Fruchtenbaum 2004:665).

While the scene depicted in verses 1-34 may appear tranquil - Jesus teaches while sitting on a boat - the tumultuous events earlier that day had far-reaching consequences. The rule of the four Gentile empires on earth could have been ended had Israel accepted the Messiahship of Jesus, but when 'this generation' blasphemed the Holy Spirit, God again revealed mysteries (vv. 1-34; cf. Mt 13:1-52). In Daniel 2, God revealed mysteries about what will happen while Israel has no king on the Davidic throne. In Mark 4, even though the Davidic Messiah had already come, Jesus was rejected by that generation in Israel (cf. Mk 1:7; 3:20-30; 12:35-37), and now God again reveals mysteries about what will happen while Israel has no king on the Davidic throne. During the Inter-Advent Period, the kingdom 'exists in this intercalation only in the sense that the sons of the kingdom are present' (Toussaint 1980:172). 'Jesus is offering new truths about the kingdom while still maintaining the expectation of the earthly kingdom as foretold by the OT prophets' (Vlach 2017:325). In agreement with Vlach (2017):

Two extremes must be avoided. First, it is wrong to deny any connection between the kingdom and the present age. The kingdom program is related to the present age in regard to the message of the kingdom and the growth of kingdom citizens. Second, it is incorrect to hold the kingdom reign itself has been established in this age. That will occur at Jesus' second coming. (p. 332)

\section{An overview of Mark 4:1-34}

Having proposed a chiastic structure for verses 1-34, and after identifying presuppositions that influence an understanding of this text, an overview of the teaching of this passage is now presented.

\section{The parable of the sower (Mk 4:2b-9)}

In the parable of the sower as presented in the Gospel of Mark, not only is Jesus the sower of the good news regarding the kingdom of God (Mk 1:14-15, 38; 2:2; 4:3), but the early chapters of Mark show the various paradigmatic responses to this proclamation. Later, with authority received from Christ, disciples also sow the word. From Christ's first advent until his return to the earth, the four different kinds of soils depict different levels of effective or ineffective hearing (vv. 4-8).

\section{Mystery of the kingdom of God (Mk 4:10-13)}

Because unbelievers have not responded to the word that has been sown, God does not give them the mystery of the kingdom (v. 11; see also Edwards 2002:133-135; Stedman 2002:117-118). If unbelievers respond to the word, God will give them the mystery, but if they do not turn to Christ and be forgiven for their sins, they will see without perception and hear but not understand (v. 12; see also 1 Cor 2:6-3:3). If the presentation of direct truth in the form of the word has not been met with an effective hearing response, Jesus still presents truth to unbelievers, but now only indirectly, through parables (vv. 11-12, 34). To Christ's followers the mystery is given by God, but even these 'insiders' still need Jesus to explain it all to them (vv. 11, 34).

\section{Interpretation of the parable of the sower (Mk 4:14-20)}

Regarding Mark's interpretation of the sower, the reception of the word is not only resisted by Satan (v. 15), but also via tribulation and persecution or by the deceitfulness of riches and other desires (vv. 16-19). Because a kingdom cannot be divided against itself (cf. Mk 3:24-27), when Christ returns to establish the Messianic kingdom, satanic opposition to the sowing of the word will cease. However, even then as now, the fallen nature of human beings could still result in ineffective hearing (vv. 16-19). Christ's followers hear and respond to the word with receptive hearts, albeit with varying degrees of fruitfulness.

\section{The parable of the lamp (Mk 4:21-23)}

Regarding the parable of the lamp, it is often thought that the light 'represents the parabolic revelation which is the subject of this chapter and in particular the secret of the kingdom of God' (France 2002:208, [author's italics]; see also Lambrecht 1977:124-125). According to this understanding of the parable:

this image tells strongly against any interpretation of vv. 11-12, which suggests that that knowledge is meant to be kept hidden rather than made as widely available as possible. (France 2002:208)

While this interpretation is popular, it may partially contradict what Jesus had just said (vv. 11-12). Part of the reason why Jesus taught in parables is to reveal new truths to his followers, but also to conceal it from outsiders (Bailey 1998a:175; Pentecost 1982:10). If unbelievers were exposed to further directly revealed truth about the mystery of the kingdom, and if they also rejected this truth, their guilt would increase (Cranfield 1966:171; Pentecost 1982:13). Of 
course, God wants outsiders to become insiders, and disciples of Jesus are to preach not only the good news (see Mk 1:14-15; 3:14), but these parables too. But 'understanding the kingdom of God is not a human ability but a capacity created by Jesus Christ within the heart of the believer' (Edwards 2002:141). It seems therefore that unbelievers will be given the mystery of the kingdom only if they turn to Christ and are forgiven (v. 11-12).

As many commentators note (Cranfield 1966:164; Edwards 2002:139; Lane 1974:165), not only is the lamp referred to with the definite article (the lamp), but the lamp is also made the subject of the sentence. Edwards (2002:139) points out that 'the reference to the lamp coming (Gk. erchetai) is more suitable of a person than an object, and has indeed been used of Jesus earlier $(1: 7 ; 3: 20)^{\prime} .{ }^{6}$ In the Old Testament, David compared God to a lamp, saying, 'You are my lamp, O LORD' (2 Sm 22:29). More specifically, in both 2 Kings 8:19 and Psalm 132:17, the Davidic Messiah is compared to a lamp. When the kingdom is established, the glory of the LORD shall be revealed to all (Is 40:5; Mk 13:26). Mark later provides a sneak preview of this light and glory of the Lord, for, on the Mount of Transfiguration, the glory of the Lord was briefly revealed before being concealed again (Mk 9:2-3; cf. also Jn 8:12). The view taken in the present article is that in this parable, Jesus is represented by the lamp that comes to bring light (see also Cranfield 1966:164-165; Edwards 2002:139-140; Lane 1974:165-167). ${ }^{7}$

If Jesus is the lamp that comes to bring light and revelation, what is the mystery being revealed? Just as a lamp comes not to be placed under a basket or a bed, but to be put on the lampstand, if Israel had accepted Jesus as the Messiah, then the unveiled glory of the King would have become visible for all to see. There is, however, indeed in verse 22 an 'explicit reference to a period of hiddenness' (Cranfield 1966:165). Because Israel did not prepare the way of the LORD as instructed (cf. Mk 1:2-3), but instead blasphemed the Holy Spirit and rejected the Messiah, the establishment of this kingdom is postponed for a time, hidden, but Christ and his kingdom will be brought to light. As noted above, three disciples were given a preview of the kingdom coming in power, of the glory of the Messiah, together with another call to listen to him (Mk 9:1-8). Lane (1974) writes that there will:

come a day when the veil is taken away and He will be known as the Bearer of the Kingdom in a disclosure which all will see. The reference is to the parousia. (p. 166)

Until then, believers must hear Christ to explain the mysteries in all these parables to them (v. 34; see also Col 2:3).

6.Other views exist. For example Hiebert (1994:155) views Mark's expression of the lighted lamp that 'comes' as a colloquial personification. France (2002:208) notes that the "unexpected use (by Mark only) of the "personal" verb हैpxहtaı when the subject is an impersonal lamp suggests to some (e.g. Cranfield, Gnilka, Hooker, subject is an impersonal lamp suggests to some (e.g. Cranfield, Gnilka, Hooker, Lane) that Mark intends us to seesus himself, whose light the use of है pxoual for 'to be brought' hardly seems so unnatural as to require it ...'

7.According to Revelation 21:23 and 22:5, in the eternal state, the New Jerusalem will not require a lamp, the sun or the moon, for the glory of God will illuminate the city. The Lamb is its light.

\section{The parable of the measure (Mk 4:24-25)}

The warning to hear is yet again sounded (v. 24a). 'Precisely because there is going to be an unveiling which unravels the enigma and reveals the mystery, hearing with true perception is important now' (Lane 1974:167). Every person will receive according to the measure of how one hears so that those who hear will be given more (see v. 24b). The passive voices of the two verbs are 'divine passives' (Edwards 2002:141): to the degree a person pays attention to what Jesus says, to that degree God blesses such hearing and graciously gives disproportionately more. Obedience to God's revealed truth results in more truth and insight being given, including better understanding of the kingdom of God (see v. 25a). For followers of Jesus, this explains the varying levels of fruitfulness that the parable of the sower mentions (vv. 8, 20). Likewise, the inverse of the same maxim is true: lack of effective hearing and response to God's revelation will eventually result in the ability to respond being lost altogether (v. 25b; cf. vv. 15-19). The mystery that the parable of the measure may reveal, is that receiving rewards of authority in the kingdom, when it is eventually established, depends on effective and continued hearing now.

\section{A unique Markan parable (Mk 4:26-29)}

There is often debate about whether this parable focuses attention on the man who sows, the seed, the period of growth, the harvest or on the contrast between sowing and the harvest (Cranfield 1966:167; Snodgrass 2008:180). Perhaps one way to synthesise many of these options is to consider the chiastic structure proposed by Fay (1989:74) so that the kingdom of God is as if a man should (see Figure 4).

As Fay (1989:74) points out, in the structure, the sowing is paralleled with the harvest in $\mathrm{A}$ and $\mathrm{A}^{\prime}$, and the activity of the man is paralleled in B and B'. There cannot be much doubt that God initiates the sowing and the harvest. In agreement with Blomberg (2012:355), being told so soon after the parable of the sower, 'the most natural interpretation would link the man who sows the seed first of all with God and then, derivatively, with Jesus and all who preach God's word'. Jesus started this sowing of the word (see Mk 1:14-15, 38; 2:2) and he is also the one with the authority to put the sickle in (v. 29; cf. J1 3:13).

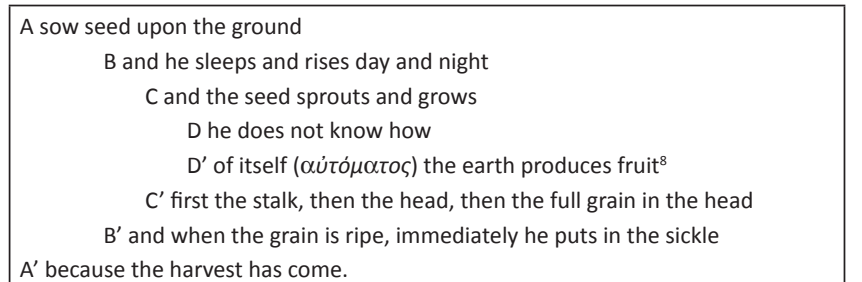

FIGURE 4: An eight-part chiastic structure.

8.'Though the English translation looks unbalanced in $\mathrm{D} / \mathrm{D}^{\prime}$, each term consists of fou Greek words' (Fay 1989:74). 
Taking this to be a parable of contrast between sowing and harvest (A and A'), Cranfield (1966:168) remarks that just as 'seedtime is followed in due time by harvest, so will the present hiddenness and ambiguousness of the kingdom of God be succeeded by its glorious manifestation'. But if this parable is indeed chiastically structured, one must at least also relate $\mathrm{A}$ and $\mathrm{A}^{\prime}$ with the centre of the parable (D and $\left.\mathrm{D}^{\prime}\right)$. As Blomberg (2012:357) fittingly notes, the 'passage is a carefully constructed unity with the beginning and ending focusing on the sower and the center underlining the role of the seed'.

The parable provides a picture of the 'time of Christ's sowing until the eschatological harvest' and so Jesus recognised that 'sowing was being accomplished in His disciples which He confidently trusted God would bring to its future fruitful consummation' (Hiebert 1994:119). God is not only involved in the sowing and the harvest, but in the entire process: it is God who causes the seed to sprout and grow (vv. 27b-28). The mystery of the kingdom that this unique Markan parable may reveal is that, from Christ's first advent until his return to the earth, God will grow a harvest of sons and daughters who will inherit the Messianic kingdom when it is established at Christ's return.

There is another aspect of this parable to consider. In this unique Markan parable, it is written that the earth brings

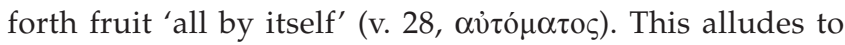
growth during a Sabbath year (Lv 25:1-7). Such growth happens after a prior sowing had already taken place, for when the farmer is inactive on the earth in obedience to God's instructions, it is God who gives the increase. Jesus is the sower who will eventually put the sickle in for the harvest. During the time that Jesus (in his humanity) is not on the earth, God ensures the success of the harvest through Christ's disciples, spearheaded by the apostle Peter, commencing on the day of Pentecost.

\section{The parable of the mustard seed (Mk 4:30-32)}

Given that Jesus is the sower in the earlier seed parables of Mark 4, it seems reasonable to conclude that he is again the implied sower. What is sown is a mustard seed and, in Mark, it is specifically sown into the ground (v. 31; see also v. 28). The mustard seed was proverbial for its smallness (Wenham 1989:53), but in this parable, when it grows, the mustard plant becomes greater than all the herbs. 'Since the comparison is with "all the seeds," a superlative meaning seems required' (Snodgrass 2008:220). This hyperbole not only emphasises the remarkable growth of this mustard seed, but also that it grows into a plant in which birds of the air may nest in its branches. The allusion to the 'birds of the air' (see Ezk 17:22-23; Dn 4:12) has Gentiles in view as the great commission moves from Jerusalem to all the nations of the world (Edwards 2002:145; France 2002:216217). This international mission commenced at Pentecost, spearheaded by the apostle Peter (Scholtz 2015:5-6).
What is the mystery of the kingdom that this parable conveys? In agreement with Bailey (1998b:458), the reference to the birds in the branches argues for more than just the contrast between small beginnings and disproportionate growth. The Old Testament teaches that when the kingdom is established, many people from all over the world will go up to Jerusalem to learn the ways of the Lord (Is 2:3; 60:3; Jr 3:17; Zch 8:20-23). The mystery that the parable of the mustard seed may teach is that, during the Inter-Advent period, many Gentiles from all over the world will turn to the Lord prior to the kingdom being established on earth. The message of the kingdom will spread across the globe, the number of people that believe this message will increase and many will experience the blessings of this kingdom when it is established (cf. Bailey 1998b:458; Vlach 2017:331).

\section{Conclusion}

This article proposed a simple structure for Mark 4:1-34, identified relevant presuppositions and then provided an overview of the content of this passage. Why did the Holy Spirit inspire Mark to string these parables together, perhaps in a structured way? The collective message that verses 1-34 may be conveying is that while the establishment of the Messianic kingdom has been postponed, God is sowing the word, not only in Israel, but all over the world. When the sowing of the word meets with a responsive ear and heart, God gives that son or daughter the mystery of the kingdom and, viewed collectively, God will bring a harvest of sons and daughters into the kingdom when it is established. It is important for all to hear, not only so that they can become believers and to bear some fruit, but also because God will graciously bless to the extent that one listens effectively. But even if you are a believer and have received the ability to understand the mystery of the kingdom of God, we still need Jesus to explain it to us. When the Lamp comes to the lampstand, we will behold the unveiled glory of the King, and his kingdom will come in power.

\section{Acknowledgements Competing interests}

The author declares that he has no financial or personal relationships which may have inappropriately influenced him in writing this article.

\section{References}

Bailey, M.L., 1998a, 'The parable of the sower and the soils', Bibliotheca Sacra 155(618), 172-188.

Bailey, M.L., 1998b, 'The parable of the mustard seed', Bibliotheca Sacra 155(620), 449-459.

Beacham, R.E., 1996, 'Universal and mediatorial kingdoms', in M. Couch (ed.) Dictionary of premillennial theology, pp. 235-237, Kregel Publications, Grand Dictionary
Rapids, Ml.

Beale, G.K. \& Gladd, B.L., 2014, Hidden but now revealed: A Biblical theology of mystery, InterVarsity Press, Downers Grove, IL.

Blomberg, C.L., 1989, 'The structure of 2 Corinthians 1-7', Criswell Theological Review 4(1), 3-20.

Blomberg, C.L., 2012, Interpreting the Parables, 2nd edn., IVP Academic, Downers Grove, IL.

Constable, T.L., 2017, Notes on Matthew, 2017 edition, viewed 30 October 2017, from www.soniclight.com 
Cranfield, C.E.B., 1966, The Gospel according to Saint Mark, University Press, Cambridge.

Dewey, J., 1980, Markan public debate: Literary technique, concentric structure, and theology in Mark 2:1-3:6, Scholars Press, Chico. (SBLDS 48).

Edwards, J.R., 2002, The Gospel according to Mark, Eerdmans, Grand Rapids, MI.

Fay, G., 1989, 'Introduction to incomprehension: The literary structure of Mark 4:134 ', The Catholic Biblical Quarterly 51(1), 65-81.

France, R.T., 2002, The Gospel of Mark: A commentary on the Greek text, Eerdmans, Grand Rapids, MI. (NIGTC).

Fruchtenbaum, A.G., 2004, The footsteps of the Messiah: A study of the sequence of prophetic events, Ariel Ministries, Tustin.

Hiebert, D.E., 1994, The Gospel of Mark: An expositional commentary, BJU Press, Greenville.

Lambrecht, J., 1977, Terwijl Hy tot ons sprak: Parabels van Jezus, Uitgeverij Lannoo, Tielt. Lane, W.L., 1974, The Gospel according to Mark, Eerdmans, Grand Rapids, MI. (NICNT) Pentecost, J.D., 1982, The parables of Jesus: Lessons in life from the Master Teacher, Kregel Publications, Grand Rapids, MI.

Scholtz, J.J., 2014, 'The kingdom of heaven and Matthew 10', In die Skriflig 48(1), Art. \#1782, 1-8. https://doi.org/10.4102/ids.v48i1.1782
Scholtz, J.J., 2015, 'Reading Matthew 13 as a prophetic discourse: The four parables presented in public', In die Skriflig 49(1), Art. \#1870, 1-7. https://doi.org/10.4102/ ids.v49i1.1870

Sider, J.W., 1995, Interpreting the parables: A hermeneutical guide to their meaning, Zondervan Publishing House, Grand Rapids, MI.

Snodgrass, K.R., 2008, Stories with intent: A comprehensive guide to the parables of Jesus, Eerdmans, Grand Rapids, MI.

Stedman, R., 2002, The Servant who rules, ed. J. Denney, Discovery House Publishing, Grand Rapids, MI.

Toussaint, S.D., 1980, Behold the King: A study of Matthew, Kregel Publications, Grand Rapids, MI.

Vlach, M.J., 2017, He will reign forever: A biblical theology of the kingdom of God, Lampion Press, Silverton.

Wenham, D., 1989, The parables of Jesus, Hodder \& Stoughton, London.

Wiley, G.W., 1985, 'A study of "mystery" in the New Testament', Grace Theological Journal 6(2), 349-360.

Woods, A.M., 2016, The coming kingdom: What is the kingdom and how is kingdom now theology changing the focus of the Church?, Grace Gospel Press, Duluth. 